\title{
EducaÇão Especial em Sergipe
}

Iranilde dos Santos Rocha SOUZA ${ }^{1}$

Certamente, você já ouviu falar em Educação Especial, talvez conheça pessoas com deficiência ou tem curiosidade em aprofundar o conhecimento sobre a história da educação especial em Sergipe. O livro Educação Especial em Sergipe Século XX: uma trajetória de descasos, lutas, dores e conquistas da doutora Rita de Cácia, publicado em 2013, apresenta mais uma importante contribuiçáo científica e social sobre o atendimento educacional e integração dos deficientes.

A obra divide-se em três capítulos: a introdução apresenta a ênfase das políticas educacionais e sociais sobre a luta por direitos humanos proporcionando a integração social das pessoas com deficiência. No Brasil, as iniciativas para o atendimento ao deficiente foram marcadas por descaso das autoridades, deixando essa responsabilidade para sociedade civil e Igrejas que começam a atender em espaços adaptados para assistência médica, ensino de higiene pessoal e pequenas oficinas. "É a partir dessa e de outras contribuiçôes [...] que surgem as possibilidades de lutar pela integração do deficiente na escola e na sociedade." (p.37).

O primeiro capítulo Educação Especial no Brasil e no mundo - um sobrevôo apresenta os antecedentes históricos, tratamentos e abordagens educacionais no Brasil e no mundo. $\mathrm{O}$ segundo capítulo Quem é o deficiente e como o sistema educacional o vem tratando mostra uma abordagem científica com conceituaçấo, modalidades de atendimento, princípios e modelo atual de atendimento educacional. Percebe-se dificuldade na realização desse estudo inovador, segundo a autora, gerada pelas controvérsias e falta de informaçóes precisas sobre fatos de interesse geral, mas o resultado demostra sensibilidade da autora para desencavar detalhes referentes à população nas diversas deficiências: deficiência visual, deficiência física, deficiência auditiva, deficiência mental, deficiências múltiplas e altas habilidades conceituando-as e mostrando as possíveis causas e prevençóes, localiza dados quantitativos de pessoas com deficiência de cada município de Sergipe e níveis de escolaridade.

O texto demostra o descaso que estavam os deficientes e a maioria fora da escola. Segundo Rita de Cássia (2013), marginalização dos PNEEé uma ação que reflete uma atitude de descrença nas possibilidades de mudanças da situaçáo da pessoa; um consenso social pessimista, fundamentado essencialmente na ideia de que a condição de incapacidade é uma condição imutável e leva à completa omissão da sociedade em relação à organização de serviços para atender às necessidades específicas dessa população.

\footnotetext{
${ }^{1}$ Epecialista em LIBRAS - Língua Brasileira de Sinais: educação especial, licenciada em Letras - Português/Inglês e membro do grupo de pesquisa do NUPIEPED (UFS). iranilde.rocha@ymail.com
} 
O terceiro capítulo Educação Especial em Sergipe, o centro da pesquisa, trata a trajetória histórica sem priorizar datas, divide-se em cinco subtítulos: o primeiro investiga as formas de atendimento aos desvalidos ou incapacitados a fim de conhecer o desenvolvimento e percepção da deficiência; $O$ segundo situa as iniciativas de Sergipe em relação ao Brasil, a trajetória da recepção das ideias e o debate sobre a implantação das primeiras iniciativas; $\mathrm{O}$ terceiro reflete sobre as iniciativas e as dificuldades na busca de definição de uma política educacional e medidas quanto formação dos recursos humanos necessários, apresentando a atuação do Estado, Munícipio, Universidades, etc.; $\mathrm{O}$ quarto apresenta o surgimento de instituiçóes relevantes que contam com a ajuda de pais, familiares e amigos dos deficientes com o objetivo de dar assistência e integrar o deficiente na sociedade, na escola e no mercado de trabalho. E o último refere-se ao que existia antes das instituiçóes; como as famílias enfrentavam o fato de ter um deficiente; o imaginário popular, as iniciativas pela cidadania e a importância do acolhimento familiar.

A autora faz um panorama histórico e estatístico da situação educacional e assistencialista dessa parcela social percorrendo os centros de atendimentos especializados, pesquisadores da área, referenciais de jornais e documentos da época, aspectos que deixam seu trabalho mais rico, diversificado e bem estruturado. Este livro tem como público alvo todos que desejam conhecer mais sobre a educação especial, sua trajetória, lutas e conquistas. Tornou-se referência na área da educação especial por tratar a temática de forma tão completa e utilizando uma linguagem simples que possibilita o acesso de leitura e compressão a todos. "Acreditamos que este trabalho também pode chegar às mãos de leigos e pesquisadores de diversas áreas, apresentamos uma síntese didaticamente estruturada para que se possa ter uma ideia geral dessa clientela da Educação Especial.” (p.49).

Dessa forma, a História da Educação Especial em Sergipe foi organizada a partir da dissertação de Rita de Cácia (2005) e tornou-se livro de referência em Sergipe. A obra é caracterizada pela contribuição social da doutora nesta área e sugestóes para novas pesquisas. A pedagogia de Comenius de ensinar a todos ajudou na tentativa de integração das pessoas com deficiência no meio escolar, porém a inclusão sempre representou muitas dificuldades e obstáculos devido à falta de profissionais qualificados e estrutura do ambiente escolar, opta-se pelas escolas especiais que surgiram com o objetivo de prestar assistência e integrar o deficiente na escola, na sociedade e no mercado de trabalho. Diante dessa obra reveladora, pode-se dizer que Rita de Cácia é formal e criativa, cultiva um certo dialogo, buscando aproximar o leitor a uma realidade que não terminou no século XX, convidando a continuar essa história.

SOUZA, Rita de Cácia Santos. Educação Especial em Sergipe (Século XX): uma trajetória de descaso, lutas, dores e conquistas. Aracaju: Criação, 2013. 